\title{
The Formation of a Dissociable Plasmid Cointegrate from the Flac Factor and the Resident Plasmid of Salmonella typhimurium LT2
}

\author{
BY V. RODRIGUEZ LEMOINE AND R. J. ROWBURY \\ Department of Botany and Microbiology, University College London, London WCIE $6 B T$
}

(Received I6 January 1976; revised 24 March 1976)

\begin{abstract}
SUMMARY
The Flac factor showed unstable maintenance in Salmonella typhimurium dnaC $\mathrm{MPIO}_{\mathrm{LT2}}$. The properties of a more stable $\mathrm{lac}^{+}$derivative (SD-I) are described. SD-I was $t s$ and carried the $f^{+}$property and the ability to transfer the $\mathrm{lac}^{+}$ character. It contained a large plasmid of molecular weight about $129 \times 10^{6}$ daltons. The properties of SD-I and its derivatives suggested that the large plasmid was a cointegrate of Flac and the $\mathrm{MPIO}_{\mathrm{LT2} 2}$ plasmid. $\mathrm{Lac}^{+}$transfer was efficient from SD-I to M799 $\mathrm{MPIO}_{\mathrm{LT2}}$ and one $\mathrm{lac}^{+}$exconjugant contained the intact cointegrate. The cointegrate was not successfully transferred to strains lacking $\mathrm{MPIO}_{\mathbf{L T 2}}$. It dissociated into apparently unaltered Flac and $\mathrm{MPIO}_{\mathrm{Lr2}}$ plasmids, but the deletion of small parts of one or both plasmids during cointegrate formation could not be ruled out. Cointegrate dissociation was more marked in M799 than in SD-I especially during growth in glucose-Casamino acids minimal medium. In the presence of $\mathrm{RI} d r d r 9$, the cointegrate (like the $\mathrm{MPIO}_{\mathrm{LT2}}$ plasmid) was stably maintained in the $d n a C$ strain; maintenance of Flac was, however, unstable. It seems likely that replication of the cointegrate was controlled by the $\mathrm{MPIO}_{\mathrm{LT2}}$ plasmid constituent.
\end{abstract}

\section{INTRODUCTION}

During previous work on plasmid replication in $d n a C$ and $d n a C^{+}$strains of Salmonella typhimurium, it was observed (Rodriguez Lemoine \& Rowbury, 1975b) that whereas Flac was stably maintained in the $d n a C^{+}$strains at all the temperatures tested, maintenance of Flac was aberrant at permissive temperatures in the temperature-sensitive dnaC mutant. After overnight growth in broth at $32{ }^{\circ} \mathrm{C}, 90 \%$ of organisms were $l a c^{-}$. Unstable maintenance was dependent on the presence of the resident plasmid as well as on the dnaC lesion. Stably $\mathrm{lac}^{+}$derivatives can be isolated from this strain and we describe the properties of one such derivative.

The resident plasmid $\mathrm{MPIO}_{\mathrm{IT2}}$ (previously called the LT2 plasmid) is a large stringently controlled plasmid of molecular weight about $60 \times 10^{6}$ daltons (Spratt, 1972; Spratt, Rowbury \& Meynell, 1973; Smith et al., 1973). The plasmid, which is apparently nontransferable, is stably maintained, but cured strains (which lack the $f^{+}$property conferred by it) have been isolated and studied (Smith et al., 1973; Spratt et al., 1973). Macrina \& Balbinder (1972) isolated a large plasmid (FlacS) from a $\mathrm{F}_{t s 114} l a c$ derivative of $S$. typhimurium. FlacS showed certain properties characteristic of $\mathrm{MPIO}_{\mathrm{LT2}}$ (Macrina \& Balbinder, I973; Rodriguez Lemoine \& Rowbury, 1975a). Nevertheless, the failure of FlacS DNA to hybridize with that of the $\mathrm{MPIO}_{\mathrm{IT2}}$ plasmid led Macrina, Balbinder \& Bassel (I973) to conclude that FlacS might not be a hybrid of $\mathrm{F}_{t 5114} l a c$ and $\mathrm{MPIO}_{\mathbf{L T 2}}$. In this paper, we describe 
the formation of a large plasmid in S. typhimurium $\mathrm{IIG} d n a C$ Flac MPIO $\mathrm{IT2}_{\mathrm{IT}}$. This plasmid is apparently a cointegrate of Flac and the $\mathrm{MPIO}_{\mathrm{LT2}}$ plasmid, since it conferred properties characteristic of both and dissociated into apparently unaltered Flac and $\mathrm{MPIO}_{\mathrm{LT2}}$ plasmids. Transfer of the cointegrate of Flac and the MPIO $\mathrm{Im}_{\mathrm{LT2}}$ plasmid was studied, since it provided a possible means of transferring $\mathrm{MPIO}_{\mathrm{LT2}}$. Maintenance of the cointegrate was also examined in the presence of another plasmid to ascertain which component governed replication.

\section{METHODS}

Bacteria. Salmonella typhimurium strains IIG, I IG MPIO ${ }_{\mathrm{LT2} 2}$, I IG MPIO $\mathrm{I}_{\mathrm{LT2} 2}$ Flac, I IG FlacS, PGI54 MPIO (Spratt et al., I973; Rodriguez Lemoine \& Rowbury, 1975b). Strain M799 FlacS was derived from strain $\mathrm{M} 799 \mathrm{MPIO}_{\mathrm{LT2}}$ by transfer of FlacS. Escherichia coli strain C600 is a KI 2 derivative and requires threonine, leucine and thiamin for growth.

Culture media. The minimal medium (MM) used was that of Davis \& Mingioli (1950). Citrate was omitted and glucose or lactose $(0 \cdot 2 \%)$ was added as energy source. Required amino acids were added at $20 \mu \mathrm{g} \mathrm{ml}^{-1}$ (L form), thiamin at $\mathrm{I} \mu \mathrm{g} \mathrm{ml}^{-1}$ and Difco vitaminfree Casamino acids at $0.1 \%$. Oxoid nutrient broth no. 2 was used as a rich liquid medium. $\mathrm{MM}$ and broth were solidified where necessary with $2 \%$ (w/v) Difco Bacto agar. To detect $\mathrm{lac}^{+}$and $\mathrm{lac}^{-}$colonies, lactose-deoxycholate (DOC) agar (Meynell \& Meynell, I970) was used.

Viable counts. The number of viable cells in cultures was measured by plating samples (suitably diluted in $0.065 \mathrm{M}$-phosphate buffer $\mathrm{pH} 7.4$ ) on nutrient agar or lactose-DOC agar, and counting colonies after 2 days incubation at $25^{\circ} \mathrm{C}$ or $30^{\circ} \mathrm{C}$.

Tests for sensitivity to $M S 2$ phage. Two methods were used: (i) $0.1 \mathrm{ml}$ portions of cultures grown overnight in broth were spread on nutrient agar plates and drops of MS2 phage $\left[0.02 \mathrm{ml} ; 1^{10}\right.$ plaque-forming units (p.f.u.) $\left./ \mathrm{ml}\right]$ were transferred on to marked areas of the plates; (ii) $0 . \mathrm{I} \mathrm{ml} \mathrm{portions} \mathrm{of} \mathrm{cultures} \mathrm{grown} \mathrm{overnight} \mathrm{in} \mathrm{broth} \mathrm{were} \mathrm{added} \mathrm{to} 2.5 \mathrm{ml}$ soft agar (nutrient broth containing $0.8 \%$ Difco Bacto agar and $0.8 \% \mathrm{NaCl}$ ) and poured on to nutrient agar plates. After setting, drops of MS2 phage (about $0.02 \mathrm{ml} ; \mathrm{I}^{10}$ p.f.u. $/ \mathrm{ml}$ ) were transferred on to marked areas of the plates. After incubation overnight at $30^{\circ} \mathrm{C}$ or $37^{\circ} \mathrm{C}$, MS2 sensitive strains showed clear areas where the phage had been placed.

Transfer of lac ${ }^{+}$character by conjugation. Donor strains were grown to late-exponential phase in broth without shaking at the appropriate temperature. Recipient strains were grown to exponential phase in broth with shaking. Recipient cells (O.I $\mathrm{ml}$ of a suitable dilution) were spread on lactose minimal agar plates containing the growth requirements of the recipient. Drops of donor culture [appropriately diluted in $0.85 \%(\mathrm{w} / \mathrm{v}) \mathrm{NaCl}$ ] were then transferred on to marked areas of the plates. $\mathrm{Lac}^{+}$exconjugants were picked after $72 \mathrm{~h}$ at $30^{\circ} \mathrm{C}$ or $48 \mathrm{~h}$ at $37^{\circ} \mathrm{C}$.

Analysis of plasmid $D N A$. The growth, labelling and lysis of cells, separation of plasmid DNA on alkaline sucrose gradients, and analysis of gradients were all performed as described previously (Spratt et al., I973; Rodriguez Lemoine \& Rowbury, 1975a). The molecular weights of plasmids were estimated from their sedimentation behaviour on alkaline sucrose gradients (Clayton \& Vinograd, I967).

Experiments with RIdrdI9. This R factor was transferred from Escherichia coli $\mathrm{J} 53$ as described previously (Rodriguez Lemoine \& Rowbury, 1975a). $\mathrm{R}^{+}$organisms were selected by plating on minimal agar supplemented with the growth requirements of the recipient and with kanamycin $\left(25 \mu \mathrm{g} \mathrm{ml}^{-1}\right)$ and chloramphenicol $\left(25 \mu \mathrm{g} \mathrm{ml}^{-1}\right)$. Where strains carrying 


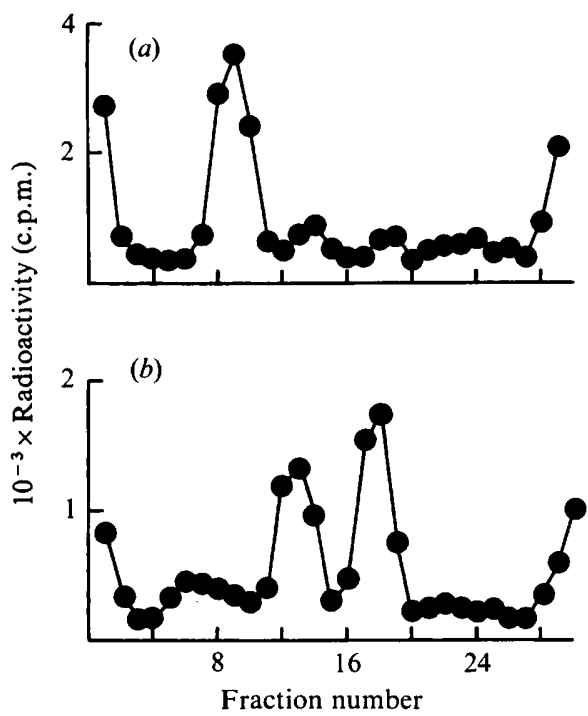

Fig. I
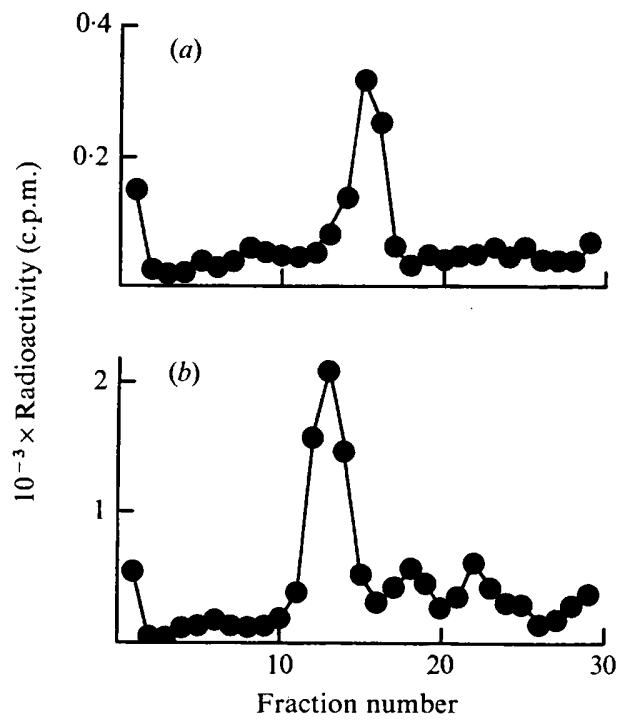

Fig. 2

Fig. I. Analysis of the plasmid content of the stably $l a c^{+}$derivative (SD-1) by alkaline sucrose gradient centrifugation. Strains IIG MPIO ${ }_{\mathrm{LT} 2}$ Flac and SD-I were labelled with $\left[{ }^{3} \mathrm{H}\right]$ thymidine in lactose-Casamino acids MM. Lysis of the organisms, sedimentation of gradients, gradient analysis and counting procedures were as described in Methods. In all figures, fraction I corresponds to the bottom of the gradient tube. (a) SD-I; (b) strain I IG MPIOLT2 Flac.

Fig. 2. Sedimentation on an alkaline sucrose gradient of the SD-I plasmid and FlacS. SD-I was grown and labelled with $\left[{ }^{3} \mathrm{H}\right]$ thymidine as described in Fig. I. Strain I IG FlacS was grown and labelled as described in Fig. I, but using $\left[{ }^{14} \mathrm{C}\right]$ thymidine $\left(4 \mu \mathrm{Ci} \mathrm{ml}{ }^{-1}\right)$ instead of $\left[{ }^{3} \mathrm{H}\right]$ thymidine. The two suspensions were then mixed and lysed together. Lysis, sedimentation and all further analytical procedures were as described in Methods. $(a){ }^{14} \mathrm{C}$ counts, i.e. plasmid content of strain IIG FlacS; (b) ${ }^{3} \mathrm{H}$ counts, i.e. plasmid content of SD-I.

$\mathrm{RI} d r d \mathrm{I} 9$ were tested for the number of $\mathrm{R}^{+}$organisms, plating was on nutrient agar with the same concentrations of kanamycin and chloramphenicol.

\section{RESULTS}

\section{A large plasmid in a derivative of Salmonella typhimurium I IG}

When S. typhimurium IIG dnaC $\mathrm{MPIO}_{\mathrm{LT2}} \mathrm{Flac}$ (parent) was plated on lactose-deoxycholate agar at $25^{\circ} \mathrm{C}$, many of the organisms formed white colonies with red centres, i.e $\mathrm{lac}^{+}$maintenance was unstable. About $0.5 \%$ of the organisms, however, formed red stably $\mathrm{lac}^{+}$colonies. One of these stably $\mathrm{lac}^{+}$derivatives (SD-I) was purified and studied.

SD-I was, like its parent, $t s$ and was able to transfer the $l a c^{+}$character to strain $M 799$ MPIO $_{\text {LT2 }}$. SD-I was, moreover, resistant to MS2 phage and therefore carried characteristics of both Flac (lac ${ }^{+}$character and transfer ability) and the MPIO $\mathrm{LTT}_{\mathrm{LT}}$ plasmid ( $\mathrm{fi}^{+}$character).

The plasmid DNA content of SD-I was compared with that of its parent by running extracts on alkaline sucrose gradients. The extract prepared from the parental culture showed the two peaks characteristic of the covalently closed circular (CCC) forms of Flac (about $\mathrm{I} \cdot 65 \%$ of the total cellular DNA as CCC plasmid) and the $\mathrm{MPIO}_{\mathrm{LT2}}$ plasmid (about I $.9 \%$ of the total cellular DNA as CCC plasmid). However, extracts of SD-I cultures contained substantial amounts (about $3.6 \%$ of the total cellular DNA as CCC plasmid) of a 


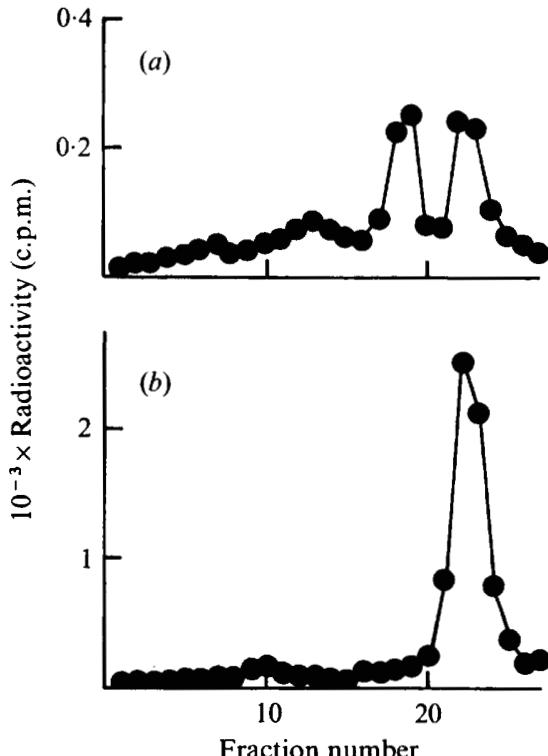

Fraction number

Fig. 3

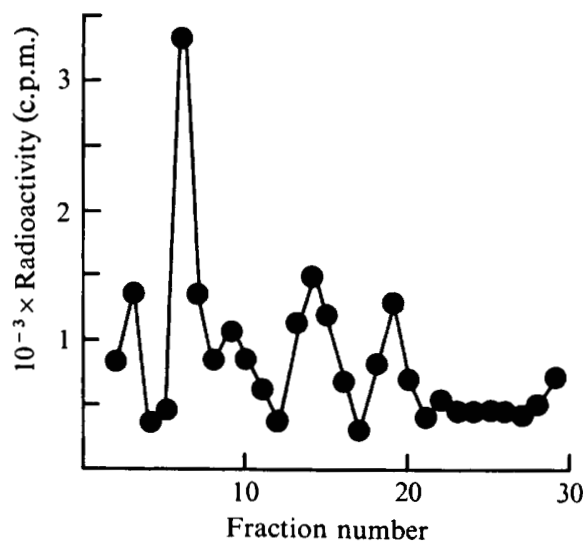

Fig. 4

Fig. 3. Analysis of the plasmid content of a $\mathrm{lac}^{-}$segregant of SD-I by alkaline sucrose gradient centrifugation. Organisms of a $\mathrm{lac}^{-}$segregant from SD-I were labelled with $\left[{ }^{3} \mathrm{H}\right]$ thymidine in glucose-Casamino acids MM. Strain PGI54 $\mathrm{MPIO}_{\mathrm{LT} 2}$ Flac was labelled with $\left[{ }^{14} \mathrm{C}\right]$ thymidine in lactose-Casamino acids MM. Cell suspensions were then mixed and lysed together. All subsequent procedures were as described in Methods. (a) ${ }^{14} \mathrm{C}$ counts, i.e. plasmid content of strain PGI54 $\mathrm{MPIO}_{\mathrm{LT2}} \mathrm{Flac} ;(b){ }^{3} \mathrm{H}$ counts, i.e. plasmid content of the lac ${ }^{-}$segregant from SD-I.

Fig. 4. Analysis of the plasmid content of a $\mathrm{lac}^{+}$exconjugant from a cross of SD-I $\times$M799 MPIO $\mathrm{ITz}_{\mathrm{IT}}$ by alkaline sucrose gradient centrifugation. The exconjugant was grown in lactose-Casamino acids MM and labelled with $\left[{ }^{3} \mathrm{H}\right]$ thymidine as described in Fig. I. Sedimentation, analysis of gradients and counting of samples were also performed as in Fig. I.

large plasmid (Fig. I), as well as smaller amounts of plasmids which behaved like Flac (about $0.35 \%$ of the total cellular DNA) and the MPIOLr2 plasmid (about $0.36 \%$ of the total cellular DNA).

The large SD-I plasmid was larger (Fig. 2) than the hybrid FlacS factor (molecular weight about $109 \times 10^{6}$ daltons; Macrina et al., 1973) and its molecular weight was estimated to be $\mathrm{I} 28 \times 10^{6}$ to $130 \times 10^{6}$ daltons. It seemed likely that the SD-I plasmid was a cointegrate of Flac and the $\mathrm{MPIO}_{\mathrm{LT} 2}$ plasmid, since SD-I had properties characteristic of both. The molecular weight estimated was somewhat less than that expected for a cointegrate made by fusion of the complete genomes of Flac (molecular weight about $80 \times 10^{6}$ daltons) and the

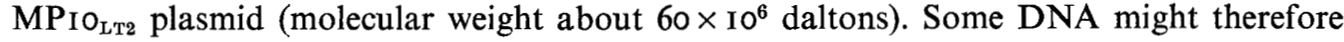
have been deleted in the fusion.

The small amounts of apparently normal Flac and $\mathrm{MPIO}_{\mathrm{LT2}}$ plasmids present in SD-I extracts might have arisen by dissociation of a cointegrate. Dissociation would result in the presence of two types of derivative in SD-I cultures. Organisms carrying the two constituent plasmids would arise directly; $l a c^{+}$maintenance should be unstable in them. From these, lac ${ }^{-}$organisms carrying only the $\mathrm{MPIO}_{\mathrm{LT} 2}$ plasmid should arise. When broth-grown cultures of SD-I were plated on lactose-deoxycholate agar at $25^{\circ} \mathrm{C}, 5$ to $6 \%$ of the organisms formed white colonies with red centres, i.e. maintenence of the $\mathrm{lac}^{+}$character was unstable in them (Table I). Organisms from one of these colonies contained plasmids which behaved like 


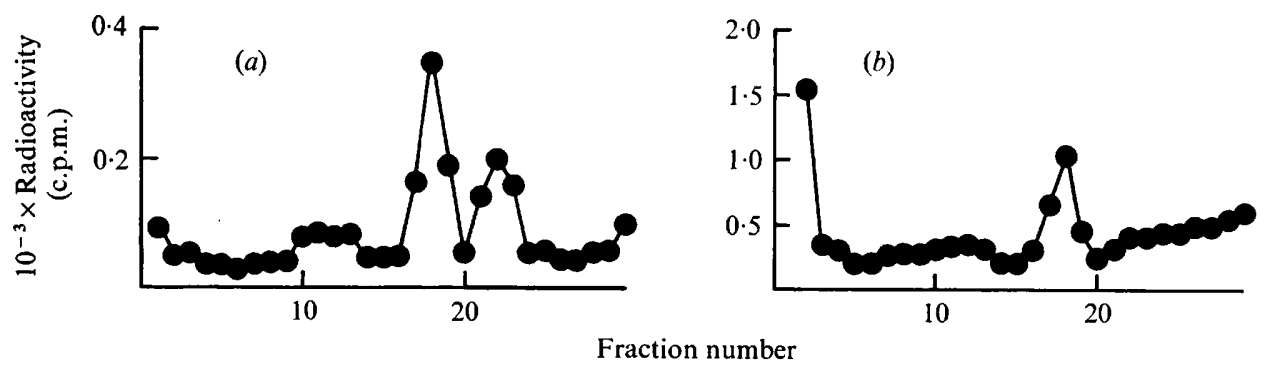

Fig. 5. Comparison of the derived Flac with the parental Flac by sedimentation on an alkaline sucrose gradient. Organisms of strain M827 carrying the derived Flac (see Table I) and strain PGI54 MPIO $\mathrm{LTT}_{2}$ Flac were labelled with $\left[{ }^{3} \mathrm{H}\right]$ and $\left[{ }^{14} \mathrm{C}\right]$ thymidine respectively in lactose-Casamino acids MM. Organisms were lysed together and treated subsequently as in Fig. 2 . (a) ${ }^{14} \mathrm{C}$ counts, i.e. plasmid content of PGI54 MPIO $\mathrm{LT}_{2} \mathrm{Flac} ;(b){ }^{3} \mathrm{H}$ counts, i.e. plasmid content of $\mathrm{M} 827$ derived Flac.

Flac and the $\mathrm{MPIO}_{\mathrm{LT} 2}$ plasmid on alkaline sucrose gradients, but the large plasmid was absent. A further 2 to $3 \%$ of the organisms from a SD-I culture formed white $\left(\mathrm{lac}^{-}\right)$colonies on lactose-deoxycholate agar. All three of these tested (e.g. Fig. 3) contained only a plasmid which behaved like MPIO $\mathrm{LT2}_{2}$.

\section{Transfer properties of SD-I}

As stated above, SD-I transferred the $l a c^{+}$character when incubated with strains such as M799 MPIO $_{\mathrm{LT2} 2}$. However, 5 to $6 \%$ of the organisms in a SD-I culture (those showing unstable $\mathrm{lac}^{+}$maintenance) probably carried Flac and these might have been responsible for all the $\mathrm{lac}^{+}$transfer. Quantitative measurements rule this out. Transfer of the $\mathrm{lac}^{+}$character to $\mathrm{M} 799 \mathrm{MPIO}_{\mathrm{LT2}}$ was somewhat more efficient from SD-I $\left(2.9 \times \mathrm{IO}^{-4} \mathrm{lac}^{+}\right.$exconjugants per donor organism) than from IIG MPIO ${ }_{\mathrm{LT2}}$ Flac $\left(2 \cdot 4 \times \mathrm{IO}^{-4}\right.$ lac $^{+}$exconjugants per donor organism). It follows that organisms carrying the cointegrate were responsible for most of the $l a c^{+}$transfer.

Extracts from one $\mathrm{lac}^{+}$exconjugant from the cross of SD-I $\times$M799 $\mathrm{MPrO}_{\mathrm{LT2}}$ contained the plasmid cointegrate (Fig. 4). Dissociation of the cointegrate was more extensive in strain M799 since substantial amounts of plasmids which behaved like Flac and $\mathrm{MPIO}_{\mathrm{LT2}}$ were also present (Fig. 4). Growth of the M799 derivative in glucose medium rather than lactose led to even further dissociation (about $\mathrm{I} \%$ of total DNA as CCC form of the SD-I plasmid in glucose-Casamino acids MM, but about $3 \%$ in lactose-Casamino acids MM).

Attempts to transfer the cointegrate into strains lacking $\mathrm{MPIO}_{\mathrm{LT2}}$ were unsuccessful. Very few $\mathrm{lac}^{+}$exconjugants arose when SD-I was crossed with M827 and these probably received only Flac since $45 / 45$ were MS2 sensitive (i.e. lacked the $f^{+}$property characteristic of MPIO $\mathrm{LT2}_{\mathrm{LT}}$ and the cointegrate) and extracts from one contained only a single plasmid which sedimented like Flac on alkaline sucrose gradients. Similarly, after a cross of M799 containing the cointegrate with IIG, the three $l a c^{+}$exconjugants tested were MS2 sensitive and one of them contained a single plasmid which behaved like Flac on alkaline sucrose gradients. When E. coli $\mathrm{C} 600$ was used as recipient in crosses with SD-I or the M799 derivative carrying the cointegrate, no $\mathrm{lac}^{+}$exconjugants were isolated.

\section{Properties of the plasmids deriving from dissociation of the SD-I plasmid}

The large plasmid of SD-I evidently arose by fusion of Flac and MPIO $\mathrm{ITT2}_{\text {Lis }}$ Its molecular weight, however, appeared to be somewhat less than the sum of the molecular weights of 


\section{Table I. Plasmid stability in derivatives of Salmonella typhimurium strain IIG}

Flac was transferred into the IIG derivatives from M827 Flac. The derived Flac originated in an unstable $\mathrm{lac}^{+}$derivative of SD-I. From there it was transferred to M827 and thence to the appropriate IIG derivatives. The strain IIG derivative carrying the derived MPIO IT2 $_{\text {plasmid was a }}$ $l_{a c}^{-}$segregant from SD-I. Organisms were taken from slopes of supplemented minimal agar plus lactose and grown overnight in broth at $30^{\circ} \mathrm{C}$. Results are expressed as percentages.

Strain

IIG Flac

I IG derived Flac

SD-I

IIG MPIO ${ }_{\mathrm{LT2}}$ Flac

I IG MPIO ITT derived Flac

I IG Flac derived MPIOLI2

I IG derived MPIO ${ }_{\mathrm{LT} 2}$ derived Flac

lac ${ }^{-}$cells
$0 \cdot 6$
$2 \cdot 0$
$2 \cdot 3$
$80 \cdot 0$
$71 \cdot 4$
$78 \cdot 0$
$80 \cdot 1$

Unstably $l a c^{+}$cells

Stably $\mathrm{lac}^{+}$cells

$\begin{array}{rr}\mathrm{NT} & \mathrm{NT} \\ \mathrm{NT} & \mathrm{NT} \\ 6 \cdot 6 & 91 \cdot \mathrm{I} \\ 19 \cdot 7 & 0 \cdot 3 \\ 28 \cdot 4 & 0 \cdot 2 \\ 21 \cdot 7 & 0 \cdot 3 \\ \mathrm{I} \cdot 4 & 0 \cdot 5\end{array}$

$\mathrm{NT}$, not tested.

the constituents. It may be that the molecular weight of large plasmids is somewhat underestimated by measurements of sedimentation in alkaline sucrose. It was possible, however, that the SD-I plasmid lacked parts of one or both constituents, as seems likely for the FlacS plasmid. Accordingly we have compared the sizes and properties of the plasmids (derived Flac and derived $\mathrm{MPIO}_{\mathrm{IT2}}$ ) formed by dissociation of the cointegrate with those of the parental Flac and MPIO $_{\mathbf{L T 2}}$ plasmids. The derived Flac co-sedimented with the parental plasmid on an alkaline sucrose gradient (Fig. 5) indicating that it was essentially unchanged in size. Transfer of the derived Flac $\left(\mathrm{I} \cdot \mathrm{I} \times \mathrm{IO}^{-2} \mathrm{lac}^{+}\right.$exconjugants per donor organism in a cross of $\mathrm{M} 827$ derived Flac $\times$ IIG $\mathrm{MPIO}_{\mathrm{LT2}}$ ) was as efficient as that of the parental Flac $\left(\mathrm{I} \cdot 0 \times \mathrm{IO}^{-2} \mathrm{lac}^{+}\right.$exconjugants per donor organism in a cross of $\left.\mathrm{M} 827 \mathrm{Flac} \times \mathrm{IIG} \mathrm{MPIO}_{\mathrm{LT2}}\right)$ and the derived Flac retained sensitivity to repression of its transfer properties by the $f^{+}$

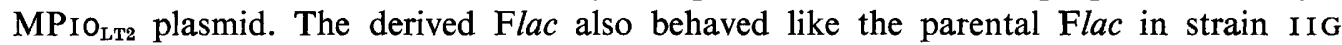
$\mathrm{MPIO}_{\mathrm{Lt2}}$. Maintenance of both was unstable and stably $\mathrm{lac}^{+}$derivatives arose with approximately equal frequencies (Table I). In a derivative of strain IIG lacking $\mathrm{MPIO}_{\mathrm{LT2}}$, both the derived Flac and the parental form were stably maintained (Table I). The derived $\mathrm{MPIO}_{\mathrm{IT2}}$ plasmid co-sedimented with the parental form on an alkaline sucrose gradient (Fig. 3). Furthermore it conferred on strain IIG the $f^{+}$property characteristic of the parental $\mathrm{MPIO}_{\mathrm{LT2}}$ plasmid. The derived $\mathrm{MPIO}_{\mathrm{LT2}}$ plasmid showed unchanged behaviour in strain IIG Flac. Its presence caused unstable maintenance of Flac and stably $l a c^{+}$derivatives arose with a frequency similar to that observed with I IG Flac carrying the parental MPIO $\mathrm{O}_{\mathrm{IT2}}$ plasmid (Table I).

The derived $\mathrm{MPIO}_{\mathbf{L T 2}}$ plasmid also retained the characteristic compatibility properties of the parental plasmid. Like the parental plasmid (Rodriguez Lemoine \& Rowbury, 1975a), it was incompatible with the hybrid FlacS as shown by the observation that introduction of FlacS into a $\mathrm{lac}^{-}$segregant derived from SD-I caused the loss of MPIO $\mathrm{Lr2}_{\mathrm{L2}}$.

\section{Control of cointegrate replication; replication in the presence of RIdrdI9}

Unstable maintenance of Flac in the $d n a C$ strain was not only caused by the $\mathrm{MPIO}_{\mathrm{IT2}}$ plasmid. Flac maintenance was also unstable (Rodriguez Lemoine \& Rowbury, 1976) in the presence of $\mathrm{R}$ factors like RIdrdI9 (6I \% of organisms were $l a c^{-}$after overnight growth of S. typhimurium dnaC Flac Ridrdr9 in broth at $30{ }^{\circ} \mathrm{C}$; $100 \%$ were $\mathrm{R}^{+}$), whereas the $\mathrm{MPIO}_{\mathrm{LT2}}$ plasmid was stably maintained with RIdrdI9 $(5 \mathrm{I} / 5 \mathrm{I}$ organisms tested were 
$\mathrm{MPIO}_{\mathrm{LT2}}+\mathrm{R}^{+}$after overnight growth of $S$. typhimurium dnaC $\mathrm{MPIO}_{\mathrm{LT2}} \mathrm{RI} d r d \mathrm{Ig}$ in broth at $\left.30{ }^{\circ} \mathrm{C}\right)$. When RIdrdI9 was introduced into SD-I, the strain remained stably $l a c^{+}(2.5 \%$ of organisms were $l a c^{-}$after overnight growth of SD-I in broth at $30{ }^{\circ} \mathrm{C} ; 2.7 \%$ were $l a c^{-}$after overnight growth of SD-I RIdrdI9 in broth at $30^{\circ} \mathrm{C}$ ). It follows that the cointegrate behaved as though its replication could be under the control of the LT2 plasmid constituent.

\section{DISCUSSION}

Flac was not stably maintained in the presence of the $\mathrm{MPIO}_{\mathrm{LT2}}$ plasmid in S. typhimurium strain I IG, but stably $\mathrm{lac}^{+}$derivatives could arise in a number of ways (Rodriguez Lemoine \& Rowbury, $1975 b$ ). The stably $l a c^{+}$character of SD-I clearly derived from the presence of a single plasmid cointegrate; single plasmids can be stably maintained in strain IIG (Rodriguez Lemoine \& Rowbury, 1975 $b$; unpublished observations). The following observations support the conclusion that the cointegrate was formed by fusion of Flac and the MPIO $_{\text {LT2 }}$ plasmid: (i) the presence of the cointegrate in SD-I was associated with substantially reduced amounts of Flac and the $\mathrm{MPIO}_{\mathrm{LT2}}$ plasmid (Fig. I); (ii) some organisms in SD-I cultures carried both Flac and the $\mathrm{MPIO}_{\mathrm{IT2}}$ plasmid and the cointegrate was absent from them.

The presence of Flac and $\mathrm{MPIO}_{\mathrm{LT2}}$ in extracts from SD-I cultures (Fig. I) suggested that the cointegrate was dissociable. The isolation of a derivative containing both Flac and $\mathrm{MPIO}_{\mathrm{LT} 2}$ from SD-I reinforced this view. The extent of dissociation was apparently increased in strain M799, especially when organisms were grown with glucose rather than lactose.

The Flac and $\mathrm{MPIO}_{\mathrm{IT2}}$ plasmids which derived from the cointegrate were not significantly altered compared to the parental plasmids with respect to molecular weight or other properties tested. This supports the view that the cointegrate contains essentially the complete genomes of the two constituents. In contrast, there was a marked discrepancy between the observed molecular weight of the cointegrate and that expected for a hybrid produced by fusion of the complete genomes of $\mathrm{Flac}$ and $\mathrm{MPIO}_{\mathrm{LT2}}$. It may be therefore that the cointegrate lacks a small part of one or both constituents. Studies of the cointegrate by restriction endonuclease 'fingerprinting' or by electron microscopy will be necessary to resolve this problem. If the SD-I plasmid does carry a deletion then this might be responsible for the failure to transfer the cointegrate to strains lacking $\mathrm{MPIO}_{\mathrm{LT2}}$.

Transferable cointegrates which have a tendency to dissociate may be useful for transferring otherwise non-transferable plasmids. The $\mathrm{MPIO}_{\mathrm{LT2}}$ plasmid has not so far been transferred as a separate unit but transfer of the SD-I cointegrate (Fig. 4) may eventually permit establishment of the $\mathrm{MPIO}_{\mathrm{Lx} 2}$ plasmid in strains lacking it.

Where plasmid hybrids are formed by the fusion of parts or the whole of two constituent plasmids then the hybrid may potentially have two distinct replication systems. Some such hybrids can apparently utilize either replication system, e.g. the replication of the hybrid pSCI 34 is governed by the ColEI constituent in the presence of chloramphenicol but by the pSCIo I constituent in polA mutants (Timmis, Cabello \& Cohen, I974). The SD-I cointegrate described here clearly contains the replication system of both constituents, since both plasmids derived from the cointegrate were able to replicate in the absence of other plasmids. In the presence of RIdrdI9, replication of the cointegrate appeared to be under the control of the $\mathrm{MPIO}_{\mathrm{LT2}}$ plasmid constituent in strain IIG since the cointegrate, like this plasmid, was stably maintained. If the cointegrate is under the control of the $\mathrm{MPIO}_{\mathrm{LT2}}$ plasmid constituent in SD-I itself then we would expect very stable maintenance since the MPIO ${ }_{\mathrm{Lr2}}$ 
plasmid and FlacS are very rarely lost from strain IIG MPIO Ir2 $_{\text {I }}$ or strain IIG FlacS (Rodriguez Lemoine \& Rowbury, 1975b). So far we have found no $l a c^{-}$segregants of SD-I which have lost the complete cointegrate; all $l a c^{-}$segregants tested carried the MPIOIr2 plasmid and therefore arose by dissociation of the cointegrate rather than by its loss. We are further examining the replication of the cointegrate to ascertain whether the $F$ factor constituent can govern replication under suitable conditions.

This work was supported by a grant (to R.J.R.) from the Central Research Fund of the University of London and by a Fellowship (to V.R.L.) from the Consejo de Desarollo, Cientifico y Humanistico, Universidad Central de Venezuela.

\section{REFEREN CES}

Clayton, D. A. \& Vinograd, J. (1967). Circular dimer and catenate forms of mitochondrial DNA in human leukaemic leucocytes. Nature, London 216, 652-657.

Davis, B. D. \& Mingioli, E. S. (1950). Mutants of Escherichia coli requiring methionine or vitamin BI2. Journal of Bacteriology 60, 17-28.

MACRINA, F. L. \& BALBINDER, E. (1972). Genetic characterization of a stable Flac. Journal of Bacteriology II2, 503-5I2.

MACrina, F. L. \& Balbinder, E. (1973). Plasmid-associated functions of a stable Flac. Journal of Bacteriology 113, I 83-I9I.

Macrina, F. L., BAlbinder, E. \& Bassel, A. (1973). Molecular characterization of a stable Flac plasmid. Biochemical and Biophysical Research Communications 54, 737-743.

Meynell, G. G. \& Meynell, E. (1970). Theory and Practice in Experimental Bacteriology, 2nd edn. Cambridge University Press.

Rodriguez Lemoine, V. \& Rowbury, R. J. (I975a). Compatibility studies with the plasmid of Salmonella typhimurium LT2. Revista latinoamericana de microbiologica $\mathbf{1 7}, 79-85$.

Rodriguez Lemoine, V. \& Rowbury, R. J. (I975 b). Instability of the Flac factor in a dnaC mutant of Salmonella typhimurium. Journal of General Microbiology 90, 360-364.

Rodriguez Lemoine, V. \& Rowbury, R. J. (1976). Unstable maintenance of F-primes induced by F-like $\mathrm{R}$ factors and a Col factor in a strain of Salmonella typhimurium. Proceedings of the Society for General Microbiology 3, 87.

Smith, H. R., Humphreys, G. O., Grindley, N. D. F., Grindley, J. N. \& Anderson, E. S. (1973). Molecular studies of an $\mathrm{fi}^{+}$plasmid from strains of Salmonella typhimurium. Molecular and General Genetics 126, I 43-I5I.

SPRATT, B. G. (1972). Replication of extrachromosomal elements in a DNA synthesis initiation mutant of Salmonella typhimurium. Biochemical and Biophysical Research Communications 48, 496-50I.

Spratt, B. G., Rowbury, R. J. \& Meynell, G. G. (1973). The plasmid of Salmonella typhimurium LT2. Molecular and General Genetics I2I, 347-353.

Timmis, K., Cabello, F., \& Cohen, S. N. (I974). Utilisation of two distinct modes of replication by a hybrid plasmid constructed in vitro from separate replicons. Proceedings of the National Academy of Sciences of the United States of America 7x, 4556-4560. 